\title{
Pengaruh Penggunaan Informasi Akuntansi terhadap Keberhasilan Usaha Mikro Kecil
}

\author{
Henny Triyana Hasibuan ${ }^{1}$ \\ Fakultas Ekonomi dan Bisnis \\ Universitas Udayana, Indonesia \\ Email: henny_triyana@unud.ac.id
}

\begin{abstract}
ABSTRAK
Informasi akuntansi merupakan catatan keuangan yang dapat digunakan oleh pelaku UMK (Usaha Mikro Kecil) untuk mengetahui berapa pendapatan yang seharusnya diterima, berapa biaya operasi yang seharusnya dikeluarkan dan berapa besarnya laba atau rugi yang diperoleh. Tujuan dari penelitian ini adalah untuk melihat pengaruh informasi akuntansi terhadap keberhasilan usahaUMK. Populasi penelitian adalah UMK sentra industri kripik tempe Sanan Kota Malang. Metode pengambilan sampel yang digunakan dalam penelitian menggunakan formula sehingga jumlah sampel sebanyak 60 pelaku UMK. Hasil penelitian menunjukkan bahwa penggunaan informasi akuntansi berpengaruh signifikan terhadap keberhasilan UMK pada sentra industri kripik tempe Sanan Malang Kota. Keterbatasan Penelitian ini hanya memfokuskan pada variabel penggunaan informasi terhadap keberhasilan usaha. Selain itu juga jawaban responden subyektif, hal ini disebabkanja waban responden mengarah kepada persepsi reponden dalam menggunakan informasi akuntansi untuk keberhasilan usaha.
\end{abstract}

Kata Kunci: Penggunaan Informasi Akuntansi; Usaha Mikro Kecil (UMK); Keberhasilan Usaha.

\section{The Effect of Using Accounting Information on the Success of Micro Small Businesses}

\section{ABSTRACT}

Accounting information is a financial record that can be used by MSEs (Micro Small Business) to find out how much revenue should be received, how much operating costs should be incurred and how much profitor loss is obtained. The purpose of this study is to look at the effect of accounting information on the success of MSE businesses. The population of the study was MSEs Tempe Chips Industry Center in Malang City. The sampling method used in the study used a formula so that the total sample was 60 MSEs actors. The results showed that the use of accounting information significantly influenced the success of MSEs in the Sanan Malang City tempe chips industry center. Limitations This study only focuses on the variable use of information on business success. In addition, subjective respondents 'answers, this is due to respondents' answers leading to the perception of respondents in using accounting information for business success.

Keywords: $\quad$ Use of Accounting Information; Micro Small Business (MSEs); Business Success.

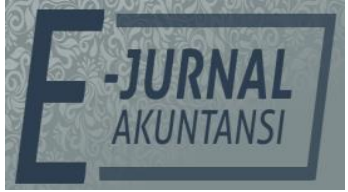

E-JA

e-Jurnal Akuntansi e-ISSN 2302-8556

Vol. 30 No. 7

Denpasar, Juli 2020

Hal.1872-1885

Artikel Masuk: 18 Juni 2020

Tanggal Diterima: 10 Juli 2020

The Article is Available in: https://ojs.unud.ac.id/index.php/Akuntansi/index 


\section{PENDAHULUAN}

Perkembangan perekonomian di Indonesia umumnya berbasis kepada ekonomi kerakyatan dengan munculnya UMKM (Usaha Mikro Kecil dan Menengah). Sektor UMKM memiliki peranan yang cukup besar baik dalam skala nasional maupun daerah. Keberhasilan usaha kecil tidaklepas dari kerja keras pemilik dalam mengelola usahanya.Salah satu faktor penyebab keberhasilan usaha yaitu diterapkannya kebijakan-kebijakan manajemen yang merupakan kunci keberhasilan suatu perusahaan dipengaruhi oleh pemilikdalam menggunakan informasiakuntansi. Nenna, (2012:52) mengemukakan The need for information is basic for concrete and explicit management decision to ensure the uccess and survival of an organization and since the aim of any business organization is profitability. Accounting information is indispensable to achieving this goal.

Informasi akuntansi merupakan catatan keuangan yang dapat digunakan oleh pemilik UMK (Usaha Mikro Kecil) untuk mengetahui berapa pendapatan yang seharusnya diterima, berapa biaya operasi yang seharusnya dikeluarkan dan berapa besarnya laba atau rugi yang diperoleh. Menurut Pinasti (2007), (201), informasi akuntansi dapat menjadi dasar yang andal bagi pengambilan keputusan-keputusan dalam pengelolaan usaha kecil, antara lain keputusan pengembangan pasar, penetapan harga dan lain- lain. Pengambilan keputusan yang tepat dapat menentukan keberhasilan dari sebuah usaha.Oleh karena itu, informasi akuntansi memiliki peran yang penting bagi pelaku bisnis dalam mencapai keberhasilan usahanya, termasuk bagi usaha mikro kecil (UKM).UKM sering mengalami kesulitan untuk menerapkan akuntansi dalam bisnisnya. Suhairi (2004) menyatakan bahwa praktek akuntansi, khususnya akuntansi keuangan pada UKM di Indonesia masih rendah dan memiliki banyak kelemahan. Kelemahan itu, antara lain disebabkan rendahnya pendidikan, kurangnya pemahaman terhadap Standar Akuntansi Keuangan (SAK) dari manajer atau pemilik dan karena tidak adanya peraturan yang mewajibkan penyusunan laporan keuangan bagi UKM.

Informasi akuntansi mempunyai pengaruh yang sangat besarpenting bagi pencapaian keberhasilan usaha, termasuk usaha kecil (Utomo,2010: 45). Hal tersebut didukung oleh penelitian Indriani (2010:51) mengemukakan Informasiakuntansi berpeengaruh terhadap keberhasilan usaha seorang pengusaha akan lebih berhasil jika dalam menjalankan usahanya dilengkapi dengan pencatatan seperti mencatat bahan baku, hasil penjualan, jumlah produksi berpengaruh terhadap keberhasilan pengusaha kecil terutama dalam hal semakin meningkatnya jumlah produksi, bertambahnya karyawan dan meningkatnya omset terujikebenarannya.Namun di sisi lain, Pinasti $(2007 ; 322)$ mengungkapkan bahwa pengusaha kecil di Indonesia tidak menyelenggarakan dan menggunakan informasi akuntansi dalam pengelolaan usahanya. Hal ini mengindikasikan bahwa pelaku Usaha Mikro, Kecil dan Menengah (UMKM) identik dengan masih kurangnya kesadaran untuk menjalankan pembukuan dengan baik dalam berbisnis.Kurangnya pengetahuan dalam pembukuan, otomatis menghambat mereka menjalankan kegiatan pembukuan keuangan. Hal ini didukung penelitian Ermaliana (2013:71) yang mengungkapkan bahwa pencatatan keuangan tidak perlu untuk dibuat karena UKM merasa kesulitan dan merasa tidak penting karena tidak berpengaruh terhadap keberhasilan 
usaha. Hal tersebut berarti bahwa pengusaha UKM kesulitan dalam membuat pencatatan karena minimnya pengetahuan pebisnis UKM dalam pembukuan juga seringkali tidak disertai dengan pemenuhan sumber daya untuk menjalankan kegiatan akuntansi bisnis. Misalnya, untuk kepentingan meminjam modal kebank. UKM mengalami masalah yang sama timbul pada tahaptahapyangserupa.Ini disebabkan perusahaan tidak memiliki informasi, baik dari dalam usaha maupun dari luar usaha.Salah satu sistem informasi yang memberikan informasi yang dibutuhkan adalah system informasi akuntansi. Ketidakmampuan akuntansi merupakan faktor utama yang menimbulkan permasalahan dan mengakibatkan kegagalan perusahaan kecil dan menengah dalam pengembangan usaha (Astuti,2007:4).

Hasil penelitian Utomo (2010:45) dan Indriani, (2010:51) tidak didukung oleh Pinasti (2007:322) dan Ermaliana (2013:71), yang mengungkapkan bahwa penggunaan informasi akuntansi dalam pengelolaan UKM tidak memiliki pengaruh kepada kegiatan usaha. Karena terjadi perbedaan hasil penilaian ini peneliti tertarik untuk membuktikan kebenarannya dengan cara melakukan penelitian ulang pengaruh penggunaan informasi akuntansi terhadap keberhasilan UMKM.

Penelitian ini mengambil objek UMK industri kripik tempe Sanan Kota Malang. Kampung Sanan merupakan salah satu sentra industri UMK di kota Malang yang perekonomiannya berkembang karena usaha keripik tempenya Karena, dikenal sebagai tempat pusat oleh-oleh keripik tempe oleh masyarakat baik dalam maupun luar kota Malang, maka bukan hal yang berlebihan jika kampung Sanan disebut sebabgai iconnya kripik tempe.Aktivitas produksi keripik tempe pelaku UMK di kampung Sanan, dikerjakan secararumahan atau home industry. Dalam proses kegiatan usahanya, mereka melibatkan orang-orang terdekat, seperti anggota keluarga, kerabat, sanak famili, ataupun orang lain yang ditengarai ikut membantu atau dipekerjakan dalam produksi keripik tempe tersebut.

Tempe sebenarnya merupakan produk andalan kelurahan Sanan Kota Malang. Sebelum dikenal sebagai sentra keripik tempe, Sanan telah lama dikenal sebagai sentra tempe. Hampir seluruh penduduk Sanan tersebut, sejak puluhan tahun lalu bergiat sebagai produsen tempe. Usaha tempe sudah menjadi usaha turun-temurun di Sanan Malang, disebabkan untuk menghindari kerugian karena tempe yang tidak laku terjual di pasar maka tempe tersebut dijadikan kripik tempe. Selain itu nilai jual produk tempe ini juga ikut terangkat. Tahun 1996 mulailah kripik tempe beroperasi di Sanan, dimulai hanya tiga UMK hingga sekarang menjadi 130 pengusaha kripik tempe.

Berdasarkan fenomena bahwa praktek akuntansi pada UMK masih rendah, namun sebenarnya informasi akuntansi dapat menjadi dasar bagi pengambilan keputusan bisnis dalam rangka mencapai keberhasilan usaha, maka penelitian ini bertujuan untuk membuktikan secara empiris pengaruh dari penggunaan informasi akuntansi terhadap keberhasilan UMK.Objek penelitian ini adalah UMKpada sentra industri kripik tempe Sanan Malang.Pemilihan sentra industri kripik tempe Sanan kota Malang dikarenakan sentra ini merupakan salah satu industri yang masih beroperasi dan berkembang pesat di Kota Malang.

Belkaoui (2000) mendefinisikan informasi akuntansi sebagai informasi 
kuantitatif tentang entitas ekonomi yang bermanfaat untuk pengambilan keputusan ekonomi dalam menentukan pilihan-pilihan diantara alternatifalternatif tindakan. Dari dua definisi tersebut dapat disimpulkan bahwa penggunaan informasi akuntansi merupakan proses, cara-cara, perbuatan menggunakan dan pemakaian informasi akuntansi untuk pengambilan keputusan ekonomi dalam menentukan pilihan-pilihan diantara alternatifalternatiftindakan.

Informasi akuntansi juga berguna dalam rangka menyusun berbagai proyeksi (Deswira et al., 2009), misalnya, proyeksi kebutuhan uang kas di masa yang akan datang, mengontrol biaya, mengukur produktivitas, meningkatkan produktivitas dan memberikan dukungan terhadap proses produksi. Informasi akuntansi memungkinkan manajemen untuk mengimplementasikan strategi dan melakukan aktivitas operasional yang diperlukan untuk mencapai tujuan organisasi secara keseluruhan (Wahyudi 2009). Informasi akuntansi merupakan informasi yang digunakan sebagai dasar evaluasi kinerja, sehingga dapat dijadikan tolak ukur dalam memberikan reward atas kinerja manajerial (Susanto2008). Informasi akuntansi pada dasarnya bersifat keuangan dan terutama digunakan untuk tujuan pengambilan keputusan, pengawasan dan implementasi keputusan-keputusan perusahaan (Holmes \& Nicholls 1988). Menurut Anthony \& Reece (1995), informasi akuntansi digolongkan menjadi tiga jenis yaitu informasi operasi, akuntansi manajemen dan akuntansi keuangan. Sedangkan Holmes \& Nicholls (1988) mengklasifikasikan informasi akuntansi dalam tiga jenis yang berbeda menurut manfaatnya bagi para pemakai, yaitu sebagai berikut, Statutory accounting information, merupakan informasi yang harus disiapkan sesuai dengan peraturan yangada, Budgetary information, yaitu informasi akuntansi yang disajikan dalam bentuk anggaran yang berguna bagi pihak internal dalam perencanaan, penilaian dan pengambilankeputusan dan additional accounting information, yaitu informasi akuntansi lain yang disiapkan perusahaan guna meningkatkan efektifitas pengambilan keputusan manajen Konsep informasi akuntansi menurut Anthony \& Reece (1995) serta Holmes \& Nicholls (1988) inilah yang akan digunakan dalam penelitian ini. Oleh karena itu, penggunaan informasi akuntansi mencakup penggunaan informasi operasi, informasi akuntansi manajemen dan informasi akuntansi keuangan yang bermanfaat untuk memenuhi peraturan yang ada, melakukan perencanaan, penilaian dan pengambilan keputusan, serta untuk meningkatkan efektifitas pengambilan keputusan manajerUKM.

Batasan UMK yang dipergunakan dalam penelitian ini mengacu pada Undang-Undang No. 20 Tahun 2008 tentang Usaha Mikro, Kecil dan Menengah. Usaha kecil adalah usaha ekonomi produktif yang berdiri sendiri, yang dilakukan oleh orang perorangan atau badan usaha yang bukan merupakan anak perusahaan atau bukan cabang perusahaan yang dimiliki, dikuasai atau menjadi bagian baik langsung maupun tidak langsung dari usaha menengah atau usaha besar yang memenuhi kriteria usaha kecil sebagaimana dimaksud dalam undang-undang ini. Usaha menengah adalah usaha ekonomi produktif yang berdiri sendiri, yang dilakukan oleh orang perseorangan atau badan usaha yang bukan merupakan anak perusahaan atau cabang perusahaan yang dimiliki, dikuasai, atau menjadi bagian baik langsung maupun tidak langsung dengan 
usaha mikro atau usaha besar dengan jumlah kekayaan bersih atau hasil penjualan tahunan sebagaimana diatur dalam undang-undangini.

Berdasarkan Undang-Undang No. 20 Tahun 2008 tersebut, klasifikasi UMK dapat dibagi berdasarkan kepemilikan aset dan omzet perusahaan yang disajikan dalam Tabel 1.

Tabel 1. Kriteria UMK

\begin{tabular}{llll}
\hline \multirow{2}{*}{ No } & \multicolumn{2}{c}{ Kriteria } \\
\cline { 3 - 4 } & & Aset & Omset \\
\hline 1 & Usaha Mikro & Maksimal 50 juta & Maksimal 300 juta \\
2 & Usaha Kecil & $>50$ juta -500 juta & $>300$ juta -2.5 Milyar \\
3 & Usaha Menengah & $>500$ juta -10 Milyar & $>2.5$ Milyar-50 Milyar \\
\hline \multicolumn{2}{l}{ Sumber: } & UUNo.20Tahun, 2008
\end{tabular}

Keberhasilan usaha biasanya diidentifikasi dengan membesarnya skala usaha yang dimilikinya, yang bisa dilihat dari volume produksi yang tadinya bisa menghabiskan sejumlah bahan baku per hari meningkat menjadi mampu mengolah bahan baku yang lebih banyak (Haryadi 1998). Menurut Haryadi (1998), kriteria keberhasilan usaha didasarkan pada jumlah karyawan (banyaknya karyawan yang bekerja, rendahnya turn over karyawannya, tingkat lamanya bekerja karyawan dan tingkat pendidikan karyawan) dan peningkatan omzet penjualan (tingkat banyaknya pesanan, tingkat promosi pesanan, tingkat harga yang ditawarkan dan tingkat penghasilan dari penjualan).

Sedangkan menurut Suryana (2003), keberhasilan usaha adalah keberhasilan dari bisnis dalam mencapai tujuannya.Kriteria keberhasilan usaha menurut Suryana (2003) meliputi meningkatnya modal, meningkatnya pendapatan, meningkatnya volume penjualan, meningkatnya output produksi serta meningkatnya tenaga kerja. Keberhasilan usaha dapat dilihat melalui kemampuan bertahan hidup dan semakin berkembangnya suatu perusahaan (Saboet 1994), antara lain dengan adanya peningkatan volume produksi; adanya tambahan tenaga kerja; adanya tambahan alat produksi dengan berharap adanya peningkatan kemampuan produksi serta adanya tambahan modal yang berasal dari laba di tahan.

Informasi akuntansi digunakan sebagai dasar untuk pengambilan keputusan bisnis, yang sangat bermanfaat dalam merencanakan, mengelola maupun mengevaluasi usaha.Dengan adanya informasi akuntansi, semua kegiatan usaha dapat dikelola dengan baik, sehingga dapat menunjang keberhasilanusaha.

Informasi akuntansi mempunyai pengaruh yang sangat penting bagi pencapaian keberhasilan usaha, termasuk UMK. Penelitian Megginson (dalam Pinasti 2007), menyatakan bahwa informasi akuntansi mempunyai peran penting untuk mencapai keberhasilan usaha, termasuk bagi usaha kecil. Informasi akuntansi dapat menjadi dasar yang andal bagi pengambilan keputusankeputusan dalam pengelolaan usaha kecil, antara lain keputusan pengembangan pasar, penetapan harga dan lain-lain. Penelitian Utomo (2010) menyatakan bahwa persepsi dan penggunaan informasi akuntansi berpengaruh terhadap keberhasilan pengusaha kecil. Namun di lain pihak, hasil penelitian Pinasti (2001) menunjukkan bahwa para pedagang kecil di pasar tradisional Kabupaten 
Banyumas tidak menyelenggarakan dan tidak menggunakan informasi akuntansi dalam pengelolaan usahanya. Keputusan-keputusan dalam pengelolaan usaha lebih banyak didasarkan pada informasi-informasi nonakuntansi dan pengamatan sepintas atas situasi pasar (Pinasti 2007).

Berdasarkan rumusan masalah, tujuan penelitian, teori -teori yang mendukung dan hasil penelitiansebelumnya, adapun hipotesis yang diajukan dalam penelitian ini yaitu:

$\mathrm{H}_{1}$ : Ada pengaruh penggunaan informasi akuntansi terhadap keberhasilan UKM.

Model yang digunakan dalam penelitian ini dapat digambarkan sebagai berikut:

\begin{tabular}{|c|}
\hline $\begin{array}{c}\text { Penggunaan Informasi } \\
\text { Akuntansi }\end{array}$ \\
\hline
\end{tabular}

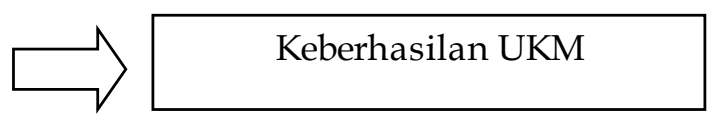

\section{Gambar 1. Model Penelitian}

Sumber: Data Penelitian, 2020

\section{METODE PENELITIAN}

Penelitian ini merupakan penelitian kuantitatif yang bersifat asosiatif kausalitas. Lokasi penelitian dilaksanakan pada Sentra kripik tempe Sanan Kota Malang. Jenis data dalam penelitin ini adalah data kuantitatif yang meliputi data skor jawaban kuesioner yang terkumpul. Sumber data yang digunakan dalam penelitian ini tergolong data primer yaitu hasil jawaban kuesioner dari responden. Seluruh pelaku usaha UMK sentra kripik tempe Sanan Kota Malang digunakan sebagai populasi dalam penelitian yang berjumlah 130 pelaku usaha UMK kripik tempe sanan Kota Malang. Sedangkan sampel dalam penelitian ini ditetapkan sebesar 60 pelaku UMK kripik tempe Sanan Kota Malang dengan pengambilan sampel diukur menggunakan formula untuk menentukan ukuran sampel (Yamane, 1973) dalam (Tania 2008).

Dalam penelitian ini variabel yang dipergunakan adalah penggunaan informasi akuntansi sbagai variabel bebas dan variabel keberhasilan usaha sebagai variabel terikat. Indikator yang dipergunakan untuk variabel penggunaan informasi akuntansi adalah informasi yang menyediakan data mentah bagi informasi keuangan seperti informasi jumlah pembeian bahan baku, pemakaian bahan baku, biaya upah dan penjualan kripik tempe. Indikator untuk keberhasilan usaha diukur dari bertambahnya karyawan, meningkatnya omset penjualan, meningkatnya penjualan dan meningkatkan pendapatan / keuntungan.

Metode pengumpulan data yang digunakan dalam penelitian ini adalah metode survei dengan teknik kuesioner mempergunakan skala likert. Analisis regresi linier sederhana dipergunakan sebagai teknik analisis, denga rumus:

$Y=a+\beta 1 P I A+\varepsilon$

Dimana:

$Y=$ Keberhasilam UMKM

PIA = Penggunaan Informasi Akuntansi

$\mathrm{E}=$ Error 


\section{HASIL DAN PEMBAHASAN}

Karakteristik responden dalam penelitian ini dideskripsikan berdasarkan jenis kelamin, usia, pendidikan terakhir dan lama menjadi pengusaha disajikan dalam Tabel 2. Tabel 2, menunjukkan bahwa, sebagian besar responden adalah berjenis kelamin perempuan, yaitu sebesar 83,33 persen dan laki-laki sebesar 16,67 persen. Hal ini dapat dipahami karena usaha industri kripik tempe sanan Malang pada umumnya merupakan usaha yang dikelola ibu rumah tangga dalam rangka membantu kepala rumah tangga untuk menafkahikeluarganya.

Berdasarkan data usia responden, sebagian besar responden berusia di atas 50 tahun sebesar 40 persen. Pada umumnya usaha industri kripik tempe Sanan Malang merupakan usaha yang diwariskan secara turun temurun. Sehingga keterampilan mereka sebagai pengusaha sudah terbina sejak mereka muda. Hal ini dapat dikatakan bahwa pada usia tersebut para responden merupakan pengusaha yang sudah berpengalaman dalam menjalankan bisnisnya.

\section{Tabel 2. KarakteristikResponden}

\begin{tabular}{lcr}
\hline \multicolumn{1}{c}{ Karakteristik } & Jumlah & Prosentase \\
\hline Jenis Kelamin & 50 & \\
Perempuan & 10 & $83,33 \%$ \\
Laki-laki & 60 & $16,67 \%$ \\
Total Jenis Kelamin & & $100,00 \%$ \\
Usia & 6 & \\
Di bawah usia 30 tahun & 14 & $10,00 \%$ \\
Usia 31 tahuns/d usia 40 tahun & 16 & $23,33 \%$ \\
Usia 41 tahuns/d usia 50 tahun & 24 & $26,67 \%$ \\
Di atas usia 50 tahun & 60 & $40,00 \%$ \\
Total Usia & & $100,00 \%$ \\
Tingkat Pendidikan & 5 & \\
SD/Sederajat & 11 & $8,33 \%$ \\
SMP/Sederajat & 27 & $18.33 \%$ \\
SMA/Sederajat & 13 & $45.00 \%$ \\
Diploma & 4 & $21,67 \%$ \\
Sarjana & 60 & $6.67 \%$ \\
Total TingkatPendidikan & & $100,00 \%$ \\
Lama Usaha & 7 & \\
<10 tahun & 14 & $11,67 \%$ \\
11 tahun -15 tahun & 18 & $23,33 \%$ \\
16 tahun -20 tahun & 21 & $30,00 \%$ \\
> 20 tahun & 60 & $35,00 \%$ \\
Total Lama Usaha & & $100,00 \%$ \\
\hline Sumber: Dat Peneitin 2020 & \\
\hline
\end{tabular}

Sumber: Data Penelitian, 2020

Berdasarkan data tingkat pendidikan, sebagian besar responden memiliki tingkat pendidikan SMA/sederajat ke bawah. Menurut responden, sebagian besar melanjutkan usaha orang tuanya. Dari kondisi tersebut dapat disimpulkan bahwa untuk melakukan usaha industri kripik tempeini tidak perlu memiliki 
jenjang pendidikan yang tinggi. Para responden berada di lingkungan bisnis industri kripik tempesejak mereka kecil, sehingga sejak dini mereka telah melihat dan terbiasa dengan bisnis kripik tempeini, baik dari usaha orang tuanya maupun dari para tetangganya.

Berdasarkan data pada Tabel 2, maka lama usaha, sebagian besar usaha telah berdiri lebih dari 20 tahun. Sanan Kota Malang adalah sentra industri tempe yang telah lama ada sejak Indonesia belum merdeka, sedangkan sentra kripik tempe dimulai sejak tahun 1996. Oleh karena itu, tidak mengherankan jika perusahaan-perusahaan pada sentra ini sebagian besar bukan merupakan perusahaan yang baruberdiri.

Tabel3, menunjukkan bahwa sebagian besar usaha industri kripik tempe di Sanan kota Malang memiliki aset yang masuk dalam kriteria usaha kecil dengan aset > Rp50 Juta sampai dengan Rp200 Juta (32 persen). Namun dari sisi omzet sabagian besar usaha termasuk dalam kriteria usaha mikro dengan omzet $\leq$ Rp300 Juta per tahun (47 persen).

Tabel 3. Karakteristik Responden Berdasarkan Aset dan Omzet Pertahun

\begin{tabular}{|c|c|c|c|c|c|c|}
\hline Jenis Usaha & Aset & Jumlah & Prosentase & Omset & Jumlah & Prosentase \\
\hline \multirow[t]{2}{*}{ Usaha Mikro } & $<50$ juta & 14 & $23,3 \%$ & $\leq$ Rp. 300 juta & 47 & $78,3 \%$ \\
\hline & $>50$ juta-200juta & 32 & $53,3 \%$ & & & \\
\hline \multirow[t]{2}{*}{ Usaha Kecil } & $>200$ juta-350 juta & 10 & $16,7 \%$ & $\begin{array}{c}\text { Pp. } 300 \text { juta }-1,5 \\
\text { Milyar }\end{array}$ & 13 & $21,7 \%$ \\
\hline & $\begin{array}{l}>350 \text { juta }-500 \\
\text { juta }\end{array}$ & 4 & $6,7 \%$ & & & \\
\hline
\end{tabular}

Jumlah

$60 \quad 100 \%$

$60 \quad 100 \%$

Sumber: Data Penelitian, 2020

Informasi akuntansi berguna bagi pemilik untuk dapat memperhitungkan keuntungan yang diperoleh, mengetahui berapa tambahan modal yang dicapai dan juga dapat mengetahui bagaimana informasi akuntansi sangat penting untuk menjalankan usaha terutama untuk mengambil keputusan untuk memecah permasalahan yang dihadapi serta untuk menyusun rencana aktivitas perusahaan dimasa yang akan datang. Dari hasil penelitian diperoleh bahwa pemilik UMK sentra industri kripik tempe Sanan Kota Malang $(59,33 \%)$ sering menggunakan informasi akuntansi, $(35,66 \%)$ kadang- kadang mempergunakan informasi akuntansi dan hanya $(23,67 \%)$ yang tidak mempergunkan informasi kuntansi. Informasi akuntansi yang paling sering dipergunakan adalah informasi pembelian bahan baku $(73,3 \%)$ hal ini disebabkan harga bahan baku kacang kedelai impor yang terkadang mengalami harga yang tidak stabil sedangkan informasi akuntansi yang paling banyak tidak dipergunakan adalah mengevaluasi kinerja karyawan (55\%) hal ini disebabkan industri kripik tempe Sanan Malang Kota merupakan industri rumahan yang banyak melibatkan anggota keluarga dan sanak saudara. Hasil penggunaan informai akuntansi terdapat pada Tabel 4. 
Tabel 4. Penggunaan Informasi Akuntansi oleh Pemilik UKM

\begin{tabular}{|c|c|c|c|c|}
\hline Keterangan & $\begin{array}{l}\text { Tidak } \\
\text { Pernah }\end{array}$ & $\begin{array}{l}\text { Kadang- } \\
\text { kadang }\end{array}$ & Sering & Total \\
\hline $\begin{array}{l}\text { Melakukan proyeksi } \\
\text { kebutuhan uangkas dimasa } \\
\text { yang akan datang }\end{array}$ & 8.3 & 16.7 & 75 & 100 \\
\hline $\begin{array}{l}\text { Mengontrol biaya dalam } \\
\text { menjalankan usaha }\end{array}$ & 0 & 16.7 & 83.3 & 100 \\
\hline Mengukur produktivitas & 18,3 & 58,3 & 23,4 & 100 \\
\hline $\begin{array}{l}\text { Memberikan dukungan } \\
\text { terhadap proses Produksi }\end{array}$ & 8.3 & 28.3 & 50 & 100 \\
\hline $\begin{array}{l}\text { Mengimplementasikan } \\
\text { strategi }\end{array}$ & 11,7 & 45 & 43.3 & 100 \\
\hline $\begin{array}{l}\text { Melakukan aktivitas } \\
\text { operasional yang diperlukan } \\
\text { untuk mencapai tujuan usaha }\end{array}$ & 13.3 & 38.3 & 48.4 & 100 \\
\hline $\begin{array}{l}\text { Mengevaluasi kinerjak } \\
\text { aryawan }\end{array}$ & 55 & 20 & 25 & 100 \\
\hline $\begin{array}{l}\text { Mengetahui jumlah produksi } \\
\text { setiaphari }\end{array}$ & 6.7 & 23.3 & 70 & 100 \\
\hline $\begin{array}{l}\text { Mengetahui jumlah } \\
\text { pembelian bahan baku }\end{array}$ & 5 & 21.7 & 73,3 & 100 \\
\hline $\begin{array}{l}\text { Mengetahui jumlah } \\
\text { pemakaian bahan baku }\end{array}$ & 10 & 38.3 & 51,7 & 100 \\
\hline $\begin{array}{l}\text { Mengetahui penggajian } \\
\text { / pengupahan ke karyawan }\end{array}$ & 45 & 38,3 & 16,7 & 100 \\
\hline $\begin{array}{l}\text { Mengetahui jumlah } \\
\text { penjualan tiapharinya }\end{array}$ & 6.7 & 40 & 53,3 & 100 \\
\hline $\begin{array}{l}\text { Merencanakan kegiatan } \\
\text { usaha }\end{array}$ & 20 & 61,67 & 18,33 & 100 \\
\hline $\begin{array}{l}\text { Mengimplementasi/menjala } \\
\text { nkan usaha }\end{array}$ & 38.3 & 41.7 & 20 & 100 \\
\hline Mengendalikan usaha & 26.7 & 53.3 & 20 & 100 \\
\hline Mengetahui posisi keuangan & 38.3 & 20 & 41,7 & 100 \\
\hline $\begin{array}{l}\text { Mengetahuikinerja } \\
\text { perusahaan }\end{array}$ & 35 & 38.3 & 26.7 & 100 \\
\hline $\begin{array}{l}\text { Mengetahui kenaikan atau } \\
\text { penurunan modal }\end{array}$ & 20 & 56.7 & 23,3 & 100 \\
\hline $\begin{array}{l}\text { Memenuhi standar peraturan } \\
\text { dari bank, } \\
\text { koperasi/Paguyuban }\end{array}$ & 21.7 & 60 & 18,3 & 100 \\
\hline $\begin{array}{l}\text { Menganggarkan usaha yang } \\
\text { mendatang }\end{array}$ & 35 & 38.3 & 26,7 & 100 \\
\hline Rata-rata & 24.42 & 37.74 & 37.85 & 100 \\
\hline
\end{tabular}

Sumber : Data Penelitian, 2020

Hasil penelitian menunjukkan bahwa pemilik UMK industri kripik tempe 
Sanan Malang setuju $(41,17 \%)$ dan sangat setuju (38,83\%) jika dikatakan usaha mereka mengalami keberhasilan, dengan indikator pesanan pelanggan meningkat $(50 \%)$ dan kepemilikan alat produksi meningkat (50\%). Tabel 5, berikut ini menyajikan keberhasilan usaha menurut pemilik UKM industri kripik tempe Sanan Malang.

\section{Tabel 5. Keberhasilan Usaha Menurut Pemilik UKM}

\begin{tabular}{|c|c|c|c|c|c|c|}
\hline Indikator & $\begin{array}{l}\text { Sangat } \\
\text { tidak } \\
\text { setuju }\end{array}$ & $\begin{array}{l}\text { Tidak } \\
\text { Setuju }\end{array}$ & $\begin{array}{l}\text { Ragu - } \\
\text { Ragu }\end{array}$ & Setuju & $\begin{array}{l}\text { Sangat } \\
\text { Setuju }\end{array}$ & Total \\
\hline $\begin{array}{l}\text { Jumlah karyawan } \\
\text { meningkat }\end{array}$ & $0,00 \%$ & $20,00 \%$ & $11,67 \%$ & $58,33 \%$ & $30,00 \%$ & $100 \%$ \\
\hline $\begin{array}{l}\text { Pesanan pelanggan } \\
\text { meningkat }\end{array}$ & $5,00 \%$ & $1,67 \%$ & $15,00 \%$ & $50,00 \%$ & $28,33 \%$ & $100 \%$ \\
\hline Omzet meningkat & $3,22 \%$ & $3,33 \%$ & $15,00 \%$ & $35,00 \%$ & $43,33 \%$ & $100 \%$ \\
\hline $\begin{array}{l}\text { Promosi produk } \\
\text { meningkat }\end{array}$ & $0,00 \%$ & $1,67 \%$ & $5,00 \%$ & $48,33 \%$ & $45,00 \%$ & $100 \%$ \\
\hline $\begin{array}{l}\text { Harga jual produk } \\
\text { naik karena } \\
\text { kualitas naik }\end{array}$ & $1,67 \%$ & $11,67 \%$ & $20,00 \%$ & $38,33 \%$ & $28,33 \%$ & $100 \%$ \\
\hline Modal bertambah & $3,33 \%$ & $3,33 \%$ & $15,00 \%$ & $35,00 \%$ & $43,33 \%$ & $100 \%$ \\
\hline $\begin{array}{l}\text { Pendapatan } \\
\text { bertambah }\end{array}$ & $0,00 \%$ & $1,67 \%$ & $6,67 \%$ & $45,00 \%$ & $46,67 \%$ & $100 \%$ \\
\hline $\begin{array}{l}\text { Penjualan } \\
\text { meningkat }\end{array}$ & $1,67 \%$ & $10,00 \%$ & $20,00 \%$ & $40,00 \%$ & $28,33 \%$ & $100 \%$ \\
\hline $\begin{array}{l}\text { Jumlah produksi } \\
\text { meningkat }\end{array}$ & $1,67 \%$ & $8,33 \%$ & $5,00 \%$ & $40,00 \%$ & $45,00 \%$ & $100 \%$ \\
\hline $\begin{array}{l}\text { Alat produksi } \\
\text { meningkat }\end{array}$ & $0,00 \%$ & $1,67 \%$ & $6,67 \%$ & $41,67 \%$ & $50,00 \%$ & $100 \%$ \\
\hline Rata-rata & $1,67 \%$ & $6,33 \%$ & $12,00 \%$ & $41,17 \%$ & $38,83 \%$ & \\
\hline $\begin{array}{l}\text { Jumlah karyawan } \\
\text { meningkat }\end{array}$ & $0,00 \%$ & $20,00 \%$ & $11,67 \%$ & $58,33 \%$ & $30,00 \%$ & $100 \%$ \\
\hline $\begin{array}{l}\text { Pesanan pelanggan } \\
\text { meningkat }\end{array}$ & $5,00 \%$ & $1,67 \%$ & $15,00 \%$ & $50,00 \%$ & $28,33 \%$ & $100 \%$ \\
\hline Omzet meningkat & $3,22 \%$ & $3,33 \%$ & $15,00 \%$ & $35,00 \%$ & $43,33 \%$ & $100 \%$ \\
\hline $\begin{array}{l}\text { Promosi produk } \\
\text { meningkat }\end{array}$ & $0,00 \%$ & $1,67 \%$ & $5,00 \%$ & $48,33 \%$ & $45,00 \%$ & $100 \%$ \\
\hline $\begin{array}{l}\text { Harga jual produk } \\
\text { naik karena } \\
\text { kualitas naik }\end{array}$ & $1,67 \%$ & $11,67 \%$ & $20,00 \%$ & $38,33 \%$ & $28,33 \%$ & $100 \%$ \\
\hline Modal bertambah & $3,33 \%$ & $3,33 \%$ & $15,00 \%$ & $35,00 \%$ & $43,33 \%$ & $100 \%$ \\
\hline $\begin{array}{l}\text { Pendapatan } \\
\text { bertambah }\end{array}$ & $0,00 \%$ & $1,67 \%$ & $6,67 \%$ & $45,00 \%$ & $46,67 \%$ & $100 \%$ \\
\hline
\end{tabular}

Sumber: Data Penelitian, 2020

Untuk menguji hipotesis penelitian adanya pengaruh penggunaan informasi akuntansi terhadap keberhasilan usaha, digunakan teknik analisis regresi linier sederhana dengan menggunakan aplikasi SPSS (Statistical Product and Service Solution) versi 16.00, dengan $a=5 \%$. Hasil uji regresi disajikan dalam Tabel 7, berikut. 
Tabel 6. Hasil Uji Regresi Sederhana

\begin{tabular}{lc}
\hline \multicolumn{1}{c}{ Keterangan Nilai } \\
\multicolumn{1}{c}{ Variabel: Penggunaan InformasiAkuntansi } \\
\hline Unstandardized Coefficients & 0,944 \\
Standardized Coefficients & 0,305 \\
Model Regresi & \\
$\mathrm{F}$ & 5,933 \\
Signifikansi & 0,018 \\
$\mathrm{R}^{2}$ & 0,593 \\
Adjusted ${ }^{2}$ & 0,677 \\
\hline
\end{tabular}

Sumber: Data Penelitian, 2020

Hasil analisis regresi pada Tabel 7, menunjukkan hasil bahwa tingkat signifikansi sebesar 0,018 lebih kecil dari 0,05 (5\%) sehingga hipotesis satu didukung dengan hasil penelitian. Hal ini menunjukkan bahwa variabel penggunaan informasi akuntansi terbukti berpengaruh secara positif terhadap keberhasilan usaha.

Berdasarkan uji hipotesis yang telah dilakukan, penggunaan informasi akuntansi terbukti berpengaruh secara positif terhadap keberhasilan usaha pada UKM sentra instri kripik tempe Sanan Malang. Hasil uji $\mathrm{R}^{2}$ pada uji hipotesis menunjukkan bahwa variabel keberhasilan usaha dapat dijelaskan oleh variabel penggunaan informasi akuntansi sebesar $59,30 \%$, sedangkan sisanya dijelaskan oleh variabel lain. Hasil penelitian ini mendukung penelitian Megginson et al. (2000) dan Utomo (2010), yang mengungkapkan bahwa informasi akuntansi mempunyai pengaruh yang sangat penting bagi pencapaian keberhasilan usaha. Menurut pengusaha kripik tempe Sanan Malang, penggunaan informasi akuntansi dapat digunakan untuk membantu manajemen perusahaan, antara lain untuk melakukan perencanaan serta membantu pengambilan keputusan dalam pengelolaan usaha. Selain itu, informasi akuntansi juga diperlukan ketika mereka hendak mengakses bantuan dari pemerintah atau tambahan modal dari kreditur (bank).

Pada dasarnya para pengusaha kripik tempe Sanan Malangsudah mempunyai kebiasaan mencatat hal-hal penting yang berkaitan dengan usahanya, meskipun pada umumnya belum menghasilkan laporan keuangan secara lengkap. Adapun jenis laporan atau catatan akuntansi yang banyak digunakan oleh pengusaha kripik tempe Sanan Malang adalah laporan atau catatan terkait barang jadi, bahan baku serta penggajian atau pengupahan karyawan (lihat Tabel 7).

Tabel 7. Laporan/Catatan Akuntansi Pengusaha Industri Kripik Tempe Sanan

$$
\text { Malang }
$$

\begin{tabular}{lcc}
\hline \multicolumn{1}{c}{ Laporan/Catatan } & Jumlah & Persentase \\
\hline Barangjadi & 55 & $91,67 \%$ \\
Bahan baku & 56 & $93,33 \%$ \\
Penggajian/upah karyawan & 15 & $25,00 \%$ \\
Pesanan & 50 & $83,33 \%$ \\
Penjualan & 45 & $75,00 \%$ \\
Biaya produksi & 35 & $58,33 \%$ \\
Kehadiran pegawai & 10 & $16,67 \%$ \\
\hline
\end{tabular}

Sumber: Data Penelitian, 2020 


\section{SIMPULAN}

Berdasarkan hasil penelitian dan pembahasan maka kesimpulannya adalah varibael penggunaan informasi akuntansi berpengaruh positif dan signifikan terhadap keberhasilan UMK pada sentra industri kripik tempe Sanan Malang Kota Ini memberi arti bahwa peningkatan penggunaan informasi akuntansi dalam aktivitas usaha yang dilakukan akan meningkatkan keberhasilan UMK.

Keterbatasan penelitian ini karena hanya memfokuskan pada variabel penggunaan informasiterhadap keberhasilan usaha. Selain itu juga jawaban responden subyektif, hal ini disebebkan jawaban responden mengarah kepada persepsi reponden dalam menggunakan informasi akuntansi untuk keberhasilan usaha.

\section{REFERENSI}

Alex Wibowo \& Elisabeth Penti Kurniawati. (2015). "Pengaruh Penggunaan Informasi Akuntansi Terhadap Keberhasilan Usaha Kecil Menengah (Studi Pada Sentra Konveksi Di Kecamatan Tingkir Kota Salatiga)". Fakultas Ekonomika dan Bisnis, Universitas Kristen Satya Wacana. Volume XVIII No. 2, 2015

Andari S. 2011. Kewirausahaan dan Manajemen Kecil. Jakarta: Salemba Empat

Aning. K Putri , Dewi Anggraini. 2016. Persepi Pengusaha Mikro Kecil dan Menengah (UMKM) Terhadap Penerapan Akuntansi Di Kota Lubuk Linggau. Jurnal Pofit Kajan Pendidikan Ekonoi dan Ilmu Ekonomi.Vol 3 No 1

Anna, Sentot Ma,ruf, Agusdiwana. 2017. Sistem Informasi Akuntansi Teori Dan Praktikal. Penerbit UM Surabaya Publing

Anthony, R. N., \& J. S. Reece. 1995. Accounting Principles. 7th ed. USA: Irwin.

Astuti, E. 2007. Pengaruh Karakteristik Internal Perusahaan Terhadap Penyiapan Dan Penggunaan Informasi Akuntansi Perusahaan Kecil Dan Menengah Di Kabupaten Kudus. Tesis Program Studi Magister Sains Akuntansi Program Pascasarjana Universitas Diponegoro

Ayu Dwi Yulianti, \& Ni Putu Wiwin Ari Susyarini. 2017. Pengaruh Penggunaan Informasi akuntansi Terhadap Keberhasilan Usaha Jasa Penginapan Bertahap Kecil.

Belkaoui, A. R. 2000. Teori Akuntansi. Edisi Pertama. Jakarta: Salemba Empat

Ermaliana, 2013. Implementasi Pencatatan Keuangan Oleh Pengusaha Mikro-Kecil Di

Kecamatan Ciputat. Jurnal Liquidity. Vol.2, No.1 Januari-Juni, hlm 66-72.

Haryadi, D., E. E. Chotim, \& Maspiyati. 1998. Tahap Perkembangan Usaha Kecil: Dinamika dan Potensi Pertumbuhan. Bandung: Akatiga.

Holmes, S., \& D. Nicholls. 1988. An analysis of the use of accounting information by Australian small business. Journal of Small Business Management. Vol.26 No.20:57-68.

I Cenik Ardana \& Endro Lukman.2016sistem Informai Akuntansi. Jakarta: Mitra Wacana Media.

Ishak dan Arif Sugiono. 2015. Akuntansi Informasi dan Dalam Pengambilan Keputusan.Cetakan Pertama.jakarta: PT Grasindo 
Indriani,N, 2010. Pengaruh Karakteristik Penggunaan Informasi Akuntansi Terhadap Keberhasilan Usaha Pada Hotel-Hotel Berbintang Di Wilayah Surakarta Dan Daerah Istimewa Yogyakarta (DIY). Universitas Gajah Mada Yogyakarta

Megginson, W. L., M. J. Byrd, \& L. C. Megginson. 2000. Small Business Management: An Entrepreneur's Guidebook. Boston: Third Ed. Irwin McGrawHill.

N. Andriani \& Zuliyati. 2015. Faktor-faktor yang mempengaruhi penggunaan informasi akuntansi (Studi Pada UMKM Kain Tenun Ikat Troso Jepara. Seminar Nasional Kebangkitan Teknologi. Universitas Muria Kudus.

Nnenna, O, 2012. The Use Accounting Information as an Aid to Management in Decision Making. British Journal of Science. May 2012, Vol. 5 (1)

Nurwani. W. Ayu Safitri. 2019. Pengaruh Penggunaan Informai Akuntansi Trehdap keberhasilan Usaha Kecil Menengah Pada Sentra Dodol di Kecamatan Tanjung Pura. Jurnal Umsu. Vol 2 No 1

Pinasti, M. 2001. Penggunaan Informasi Akuntansi Dalam Pengelolaan Usaha Para Pedagang Kecil Di Pasar Tradisional Kabupaten Banyumas. Jurnal Ekonomi Bisnis dan Akuntans. Vol.3 No.1.

Pinasti, M. 2007. Pengaruh penyelenggaraan dan penggunaan informasi akuntansi terhadap persepsi pengusaha kecil atas informasi akuntansi: suatu riset eksperimen. Jurnal Riset Akuntansi Indonesia. Vol. 10 No. 3 (September): 321-331.

R Kusumadini, I Ghozali. 2016. Analisis Faktor-faktor Yang Mempengaruhi Penggunaan Informasi Akuntansi Pada Usaha Kecil dan Menengah (Studi Kasus pada Usaha Kecil dan Menengah Bidang Furnitur di Jawa Tengah). Skripsi. Fakultas Ekonoi dan Bisnis. Universitas Diponegoro

Romney, M.B \& Steinbart, P.J. 2015. Sistem Informasi Akuntansi (ikin Sakinah Nur Safira dan Novita Puspasari Penterjemah). Jakarta: Salemba Empat

Sugiyono. 2010. Metode Penelitian Bisnis. Bandung: Alfabeta.

Suryana, 2003. Kewirausahaan.Salemba Empat: Jakarta.

Salehi, M and Abdipur. 2013. Acconting Information System's Barness: Case of and Emerging Economy African. Journal Of Business Management. Volume 7. Pp 298-305. February

Suhairi. 2004. Persepsi akuntan terhadap overload standar akuntansi keuangan (SAK) bagi usaha kecil dan menengah. Simposium Nasional Akuntansi IX, Padang.

Susanto, Y. K. 2008. Partisipasi anggaran, ketidakpastian tugas, penggunaan informasi akuntansi untuk evaluasi kinerja dan perilaku managerial.Jurnal Akuntansi dan Keuangan Indonesia.Vol.5 No.1.

Tania. 2008. Pengaruh pengalaman usaha dan pengetahuan akuntansi terhadap penggunaan informasi akuntansi pada usaha dagang di kota Salatiga. Skripsi. Fakultas Ekonomika dan Bisnis Universitas Kristen Satya Wacana Salatiga.

Utomo, W. P. 2010. Pengaruh persepsi dan penggunaan informasi akuntansi terhadap keberhasilan pengusaha tanaman hias di Surabaya. Skripsi. Universitas Pembangunan Nasional (UPN). Jawa Timur.

Undang-Undang Republik Indonesia Nomor 20 tahun 2008.Tentang Usaha Mikro, kecil dan menengah 
Wibowo. R, 2012. Pengaruh Modal, Tenaga Kerja, Bahan Baku, Mesin Terhadap Produksi Industri Kecil Konveksi Desa Padurenan Kecamatan Gebog Kabupaten Kudus. Jurnal Economics Development Analysis Journal. EDAJ 1 (2) (2012)

Wahyudi, M. 2009. Analisis faktor-faktor yang memengaruhi penggunaan informasi akuntansi pada usaha kecil dan menengah (UKM) di Yogyakarta. Tesis. Program Pascasarjana Universitas Diponegoro

Yanuar. Lazuardi. Fuad A.Salam.2019. Pengaruh Penggunaan Sistem Informasi AkuntansiTerhadap KeberhasilanUsaha Kecil Menengah. Jurnal Ilmiah Akuntansi Peradapan. Vol 5 No 2

Yohanes. Hendri A dan Theresia Woro. D. 2017. Niat Melakukan Pencatatan Akuntansi Pada Usaha Kecil Menengah. Pengetahuan AkuntansiAtaukah Herding. Jurnal Ekonomi dan Bisnis. Vol 20. No 2. 